\title{
Addressing women's construction health and safety needs in Africa
}

\begin{tabular}{|c|c|}
\hline $\begin{array}{l}\text { Authors: } \\
\text { Samuel H.P. C } \\
\text { Nathan Kibwa } \\
\text { Sibusiso Moyc }\end{array}$ & $\begin{array}{l}\text { ikafalimani }{ }^{1} \\
\mathrm{mi}^{2} \text { (D) } \\
3^{3}\end{array}$ \\
\hline $\begin{array}{l}\text { Affiliations: } \\
{ }^{1} \text { Department } \\
\text { Management } \\
\text { Surveying, Fac } \\
\text { Engineering a } \\
\text { Environment, } \\
\text { University of } \\
\text { Durban, South }\end{array}$ & $\begin{array}{l}\text { f Construction } \\
\text { and Quantity } \\
\text { ulty of } \\
\text { ad the Built } \\
\text { Durban } \\
\text { echnology, } \\
\text { Africa }\end{array}$ \\
\hline $\begin{array}{l}\text { 2Department } \\
\text { Economics an } \\
\text { School of the } \\
\text { Environment, } \\
\text { University, Ka। }\end{array}$ & $\begin{array}{l}\text { f Construction } \\
\text { Management, } \\
\text { Built } \\
\text { Makerere } \\
\text { mpala, Uganda }\end{array}$ \\
\hline $\begin{array}{l}{ }^{3} \text { Research, Inn } \\
\text { Engagement, } \\
\text { University of } \\
\text { Durban, South }\end{array}$ & $\begin{array}{l}\text { ovation and } \\
\text { Durban } \\
\text { echnology, } \\
\text { Africa }\end{array}$ \\
\hline $\begin{array}{l}\text { Correspondin } \\
\text { Samuel Chika } \\
\text { samuelc@dut }\end{array}$ & $\begin{array}{l}\text { g author: } \\
\text { alimani, } \\
\text { ac.za }\end{array}$ \\
\hline $\begin{array}{l}\text { Dates: } \\
\text { Received: } 18 \text { I } \\
\text { Accepted: } 20 \\
\text { Published: } 21\end{array}$ & $\begin{array}{l}\text { May } 2021 \\
\text { Aug. } 2021 \\
\text { Oct. } 2021\end{array}$ \\
\hline $\begin{array}{l}\text { How to cite th } \\
\text { Chikafalimani, } \\
\text { Kibwami, N. \& } \\
\text { 2021, 'Addres } \\
\text { construction } ~ \\
\text { safety needs i } \\
\text { HTS Teologies } \\
\text { Theological St } \\
77(2) \text {, a6849. } \\
\text { org/10.4102/ }\end{array}$ & $\begin{array}{l}\text { is article: } \\
\text { S.H.P., } \\
\text { Moyo, S., } \\
\text { ing women's } \\
\text { ealth and } \\
\text { Africa', } \\
\text { Studies/ } \\
\text { udies } \\
\text { ttps://doi. } \\
\text { tts.v77i2.6849 }\end{array}$ \\
\hline $\begin{array}{l}\text { Copyright: } \\
\text { (c) 2021. The } A \\
\text { Licensee: AOS } \\
\text { is licensed unc } \\
\text { Creative Comr } \\
\text { Attribution Lic }\end{array}$ & $\begin{array}{l}\text { uthors. } \\
\text { S. This work } \\
\text { ler the } \\
\text { nons } \\
\text { ense. }\end{array}$ \\
\hline Read online: & \\
\hline 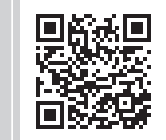 & $\begin{array}{l}\text { Scan this QR } \\
\text { code with your } \\
\text { smart phone or } \\
\text { mobile device } \\
\text { to read online. }\end{array}$ \\
\hline
\end{tabular}

Authors:

Nathan Kibwami²

Sibusiso Moyo $^{3}$

\section{Affiliations:}

Surveying, Faculty of

Engineering and the Built

Environment, Durban

University of Technology,

${ }^{2}$ Department of Construction

Economics and Management,

School of the Built

Environment, Makerere

${ }^{3}$ Research, Innovation and

Engagement, Durban University of Technology,

Corresponding author: Samuel Chikafalimani,

Dates:

Accepted: 20 Aug. 2021

How to cite this article:

Chikafalimani, S.H.P.

Kibwami, N. \& Moyo, S.

construction health and

safety needs in Africa',

HTS Teologiese Studies/

Copyright:

Licensee: AOSIS. This work

is licensed under the

Creative Commons

Attribution License.

mobile device
Concerns have been raised in Africa to address women's construction health and safety needs adequately. These concerns include less participation of women in the sector, low income and less benefits being given to women, lack of adequate protective construction clothing suited for women, unfavourable employment conditions for women, and lack of construction site security and other facilities for women. This research article provides an overview of the suggested solutions to address the concerns raised. In addition, practical interventions being implemented by the Durban University of Technology and Makerere University research collaboration project team to address women's needs in construction health and safety through women empowerment and involvement in construction research, education and practice in Africa are outlined. The main approaches applied in this research study are as follows: use of relevant publications on women's construction health and safety needs in Africa and analysis of data obtained from reliable construction professional bodies in South Africa and Uganda to demonstrate gender imbalances.

Contribution: The main contribution of this study was to emphasise the significance of including and involving women in construction research, education and practice as a major solution to address women's health and safety needs in Africa in the future as women are in a much better position to understand their own needs than men.

Keywords: women's health and safety; construction research and education; construction practice; construction industry; Africa.

\section{Introduction}

In Africa, concerns have been raised towards women's construction health and safety needs (Okwel, Alinaitwe \& Kalumba 2019; Oyewobi et al. 2019). These challenges have been compounded with minimal participation of women in construction research, education and practice in Africa. This is an undesirable situation as women are more capable than men to find appropriate solutions to meet their own construction health and safety requirements in the future (Strachan et al. 2018; Zengin-Arslan 2002). In response to these concerns, Durban University of Technology (DUT) in South Africa and Makerere University (MAK) in Uganda decided to incorporate a research objective to prioritise women's construction health and safety in Africa in a Memorandum of Understanding (MOU) signed on 05 December 2018 for their research collaboration project. In order to achieve this research objective effectively, the research collaboration project team together with its partners has encouraged women to participate in its areas of involvement in construction research, education and practice in Africa. Table 1 shows the numbers of research collaboration project team supervisors and administrators, and postgraduate research students registered for Masters and Doctorate degrees at DUT in year 2021. As noted from Table 1, out of 31 members from the DUT-MAK research collaboration project team, 14 are female research supervisors, administrators and postgraduate students, representing $45 \%$ of the team. This female representation provides strong evidence that the DUT-MAK research collaboration project intends to effectively address women's construction health and safety needs in Africa by encouraging them to participate in construction research and education. Of significance in this representation are the postgraduate construction female students. When these female students graduate, they are expected to be employed as academics and researchers in construction health and safety at universities and research centres on the African continent. Therefore, apart from being empowered to meet their own construction women's health and safety needs by the research collaboration project, they will progressively support in the future in the processes of increasing the much required pool of highly qualified women in construction research, education and industry in Africa to participate in more important work earmarked for further improvement of women's

Note: Special Collection: Gender Justice, Health and Human Development, sub-edited by Cheryl Potgieter (Durban University of Technology) 
TABLE 1: Durban University of Technology-Makerere University research collaboration project team members in year 2021.

\begin{tabular}{llc}
\hline Description & Number \\
\hline 1 & Supervisors and administrators: & \\
& Females & 10 \\
& Males & 12 \\
2 & Postgraduate construction research Masters and Doctorate students: \\
& Females & 4 \\
& Males & 5 \\
\hline Total & $\mathbf{3 1}$ \\
\hline
\end{tabular}

Source: DUT-MAK Research Collaboration Project, 2021

construction health and safety in their respective countries and communities on the continent.

\section{Literature review}

Several studies have been conducted in Africa to assess the needs of women's construction health and safety. English, Haupt and Smallwood (2006) and Alewi, Talukhaba and Opaleye (2016) examined perspectives of women, construction health and safety requirements in South Africa and Tanzania. They lamented that in the 21st century there is still less participation of women in the construction industry in Africa. This was supported by the Construction Industry Development Board (CIDB) (2020) report on the status of the South African construction industry, which states that women's contribution to the construction work force has been about $13 \%$ over the past 10 years. This undesirable gender employment inequality has economically worsened women's construction health and safety in Africa.

Studies conducted in Tanzania and South Africa on gender assessment for construction work force revealed that with no shortages of male labourers in these countries because of high unemployment, most women have no direct roles in the construction industry, except mostly as lowly paid construction work helpers on construction sites (Alewi et al. 2016; CIDB 2020; English et al. 2006). The authors further argued that these women have also received fewer benefits, including lack of medical support and childcare from there construction employers. In the process, this gender income and benefits imbalance have further financially marginalised women in the construction industries of these countries and exposed them to more health and safety challenges.

In Uganda, construction site accidents contribute towards a high number of deaths, including women on construction sites in the country, partly caused by a lack of suitable protective construction clothing and equipment in the country (Okwel et al. 2019). Additional studies conducted by Oyewobi et al. (2019) in Nigeria and by Chiocha, Smallwood and Emuze (2011) in Malawi showed that current construction industry practices in these countries ignored too adequate protective constructive clothing and equipment suited for women on construction sites. This not only seriously exposed the women to construction site accidents but also undermined their dignity in society for not being considered in the design and provision of suitable protective construction clothing and equipment, which met their requirements.
Lack of security, high cases of sexual harassment and undermining of women by men on construction sites are other concerns that have affected women in South Africa, Tanzania, Nigeria and Malawi (Alewi et al. 2016; Chiocha et al. 2011; Okonkwo 2019). These challenges and hostilities have impacted negatively the construction profession in Africa by discouraging the entry of more women workers into the construction industry.

Construction studies undertaken in South Africa and Nigeria also revealed that the construction employers disregarded the physiological differences in women and men, which made male workers endure construction work more than female workers (Okonkwo 2019; Oyewobi et al. 2019). As by nature, construction work is hard, construction employers must be considerate with women on construction sites.

The findings revealed by the International Labour Organization (2010), World Health Organization (2011) and World Bank (2019) have highlighted that employment conditions for women on construction sites in Africa were unfavourable and did not match well with their responsibilities as mothers and caregivers to their families, communities and countries. These poor working conditions contributed negatively to construction women's work performance, health and safety, eventually forcing them to stop working in the construction sector. This study identifies practical solutions to address these concerns on women's construction health and safety in Africa through the reviewed literature and by drawing on practical interventions being implemented by the DUT-MAK research collaboration project.

\section{Research methodology}

The mixed research method (Creswell 2014), which involves a combination of multiple data gathering techniques including document and report analysis, was used to collect data for the study specifically on women's construction health and safety needs in Africa, which was categorised into three main groups. Firstly, a literature search for relevant research publications and reports on important women's construction health and safety concerns raised in Africa was undertaken. Secondly, analysis of data from construction professional bodies in Africa was performed to collect information on gender imbalances for construction workers wherever applicable. Thirdly, relevant data and reflections from the DUT-MAK research collaboration project were used to demonstrate how women's construction health and safety concerns can be addressed in Africa through construction research, education and good industry practices. Data collected on women's construction health and safety concerns from different countries in Africa were limited to data that was easily accessible through the internet and written in English language.

\section{Findings, analysis and discussion}

The findings of the study on concerns raised in Africa on women's construction health and safety needs are critical. 
The raised concerns together with their proposed solutions are analysed and discussed in the subsequent section.

\section{Less participation of women in construction}

Through the study, less participation of women in the construction industry has emerged to be one of the major concerns on the African continent. Table 2 shows that in Uganda, female registered construction and land surveyors represented $25 \%$ of the total registered construction and land surveyors in the country in the year 2021 (ISU 2021). In South Africa, female construction workers represented only $13 \%$ of the total construction workers in the year 2020 (CIDB 2020), as shown in Table 3. These gender employment proportions are, indeed, disappointing as they emphasise the fact that men have dominated the construction industry in Africa, leaving women with a small portion of participation and marginalised in the sector. Norberg and Johansson (2021) suggested that deliberate construction profession and career awareness campaigns led by government and relevant partners be directed at girls in schools in Africa in order to motivate and encourage them to take careers in construction as one of the major solutions, which can be used to address this gender participation imbalance in the sector on the continent in the future. In addition, Norberg and Johansson (2021) recommended that government and the construction industry should work together on laws and policies that can be used in the sector to encourage construction employers create conducive working environment to attract women to join the construction profession. All these measures could be effective in improving the needs of women's construction health and safety on the African continent in the future. In this context, the DUT-MAK research collaboration project will also contribute by increasing the participation of women in construction skills and research and encouraging other women to take part in the construction industry in Africa in the future.

\section{Lower income and less benefits for women in construction}

The widening gender income and benefits inequality gap characterising the construction industry is highly prevalent in countries on the African continent (Okonkwo 2019; Oyewobi et al. 2019). They added that the construction

TABLE 2: Land, valuation and quantity surveyors in Uganda, 2021.

\begin{tabular}{|c|c|c|c|c|c|c|}
\hline Gender & $\begin{array}{l}\text { Year: } \\
2019\end{array}$ & $\begin{array}{l}\text { Year: } \\
2020\end{array}$ & $\begin{array}{l}\text { Year: } \\
2021\end{array}$ & $\begin{array}{c}\% \\
2021\end{array}$ & $\begin{array}{c}\text { Growth: } \\
\text { 2019-2020 } \\
(\%)\end{array}$ & $\begin{array}{c}\text { Growth: } \\
\text { 2020-2021 } \\
(\%)\end{array}$ \\
\hline Female & 299 & 360 & 371 & 25 & 20 & 3 \\
\hline Male & 933 & 1064 & 1092 & 75 & 14 & 3 \\
\hline Total & 1232 & 1424 & 1464 & 100 & 16 & $3 \%$ \\
\hline
\end{tabular}

Source: Institution of Surveyors of Uganda (ISU) Annual Report, 2021, Gender statistics, ISU, Kampala

TABLE 3: Construction workers in South Africa, October 2020.

\begin{tabular}{lcc}
\hline Gender & Year: October 2020 & \% \\
\hline Females & 138580 & 13 \\
Males & 924420 & 87 \\
\hline Total & $\mathbf{1 0 6 6 0 0 0}$ & $\mathbf{1 0 0}$
\end{tabular}

Source: Construction Industry Development Board (CIDB) Quarterly Monitor, 2020, Construction employment in South Africa, CIBD, Johannesburg industry itself and governments on the continent as partners must play key roles in the improvement of construction research skills and education for women on the continent. Furthermore, Okonkwo (2019) and Oyewobi et al. (2019) proposed that governments and their partners together must make resources available in the form of bursaries, scholarships and grants to enable women attend higher education in construction and research skills at universities on the continent in order to support them train and graduate as specialised construction professionals. These highly qualified construction women professionals will qualify for high positions in the construction industry on the continent and earn equally higher incomes like men in the sector. This could eventually address most of the needs of women in construction health and safety in Africa in the future and minimise the income inequality gap between the two genders. The DUT-MAK research collaboration project will also help by ensuring that the women involved in the project qualify for promotions and associated income increases.

\section{Lack of suitable protective construction clothing and equipment for women}

For many years, construction work in Africa has been associated with the male gender (Alewi et al. 2016; Okonkwo 2019). Over the years, this has resulted in the preference of design and procurement of construction protective clothing and equipment suitable for use by men only and not fitting women in construction satisfactorily. Okonkwo (2019) and Okwel et al. (2019) identified a change in the management style and attitudes of construction employers to start taking women's needs in construction protective clothing and equipment seriously in order to support them work to comfortably and protect them from construction site accidents. This includes introduction of purchase processes in the construction organisations that recognised procurement of construction protective clothing and equipment suitable for use by women as well. Ghani (2017) and the American Society of Safety Professionals (2021) proposed intensive innovation and design in the area of suitable protective clothing and equipment for women in construction to meet their needs. South Africa and most African countries have introduced Occupational, Health and Safety laws amongst others to encourage construction employers to comply with the provision of suitable protective construction clothing and equipment to all construction workers, including women. What is required in the future is more enforcement by governments and their partners through construction site inspectors to ensure that construction employers are providing suitable protective clothing and equipment to their employees.

\section{Unfavourable employment conditions for construction women}

Many forms of unfavourable employment conditions for women working on construction sites have been reported in Africa, including long and abnormal working hours, sexual harassment and discrimination, increased risk of musculoskeletal disorders (MSD), and reproductive hazards 
(International Labour Organization 2010; World Bank 2019; World Health Organization 2011). It is common for construction employers to expose their employees to long and abnormal working hours in order to deliver and complete construction projects within acceptable cost, time and quality for their clients. Unfortunately, Oyewobi et al. (2019) noted that this has been detrimental to their employees' health and safety, more especially for construction women workers who are exposed to uncomfortable working hours, indeed, ignoring their family and childcare responsibilities in the construction work allocation. Women construction workers have also complained of sexual harassment and discrimination on construction sites, and surprisingly, their employers do not attend to these reported incidences to the satisfaction of the women (Alewi et al. 2016). Furthermore, according to Alewi et al. (2016), another serious concern is the women on construction sites being exposed to increased risk of MSDs caused by lifting heavy objects are becoming more vulnerable to MSD than men because of their physiological nature. Sadly, Ghani (2017) lamented further by noting that women construction workers can also be exposed to reproductive hazards on construction sites caused by inhalation of toxic chemicals. Based on all these challenges, International Labour Organisation (2010), World Health Organization (2011) and World Bank (2019) suggested to construction employers to introduce comfortable employment conditions and workplace environment for women on construction sites in order to improve their work productivity, health and general wellbeing. In the South African context, construction employers are legally bound to follow the Employment Equity laws, which emphasise on offering fair employment conditions to all workers, including construction women workers as this is one of their fundamental constitutional rights. Trade unions have also generally played active roles to protect workers' rights in South Africa and other African countries.

\section{Lack of construction site security and other facilities for women}

Incidences of lack of adequate security and other facilities, including dirty toilets for women workers on construction sites in Africa, have again raised more concerns (Alewi et al. 2016; Okonkwo 2019). Temporary construction site toilets more often are dirty and have doors that are not securely lockable or not functioning properly, creating serious security and health threats to women working on construction sites. Norberg and Johansson (2021) suggested that construction employers should ensure that security and all essential facilities are provided for women on construction sites in order to retain them on their jobs.

\section{Conclusion and further research}

Concerns have been raised in Africa to adequately address the needs of women's construction health and safety. In order to identify the concerns raised, two main research approaches were applied to collect information for the study, namely, use of relevant publications on women's construction health and safety needs in Africa and analysis of data obtained from reliable construction professional bodies in
South Africa and Uganda to demonstrate gender imbalances. In addition, practical interventions being implemented by the DUT-MAK research collaboration project aimed at addressing women's needs in Africa through women empowerment and involvement in construction research, education and practice on the continent were outlined in the study as supporting data to show how organisations in the continent can practically address needs of women on construction sites. Less participation of women in the sector, low income and less benefits being given to women, lack of adequate protective construction clothing and equipment suited for women, unfavourable employment conditions for women, and lack of construction site security and other facilities for women were main concerns identified by the study on women's health and safety in Africa. The main purpose of this study was to emphasise the significance of including and involving women in construction research, education and practice as a major solution to address women's health and safey needs in Africa in the future as women are in a much better position to understand their own needs than men. This has been demonstrated practically through the DUT-MAK research collaboration project as a model for implementing the recommended solutions by the study in Africa.

The following specific recommendations have been made by the study in order to address women's construction health and safety concerns and needs in Africa:

- Include and involve women in the formulation and implementation of solutions in order to address women's needs and concerns in construction in Africa. This recommendation will further improve the proportion of women construction professionals participating in the construction industry in Africa in the future.

- Implementation of construction education, profession and careers campaigns targeted at girls in schools to encourage them to join the construction profession. This recommendation will, indeed, improve the proportion of women construction professionals to participate in construction in Africa in the future.

- Governments and relevant partners should introduce and implement laws and policies to encourage construction employers to comply and create a comfortable working environment for women on construction sites in Africa. This recommendation will improve women's health and safety in Africa.

- Governments and the private sector should make resources available in the form of bursaries, scholarships and grants in order to enable women attend higher education in construction and research at universities on the African continent to support them to graduate as construction professionals. This recommendation will support women in construction in Africa to earn high income and benefits as they will be highly qualified.

- Governments and their partners must offer education and training to construction employers to supply adequate and suitable protective construction clothing and equipment to women in construction. This recommendation will 
further attract women to work in construction and minimise construction site accidents in Africa.

- Governments and their partners should intensify inspection of construction organisations and sites to ensure that fair employment conditions are being offered to women in construction in Africa. This recommendation will support the construction industry to retain women as workers in the sector.

- Governments and their partners must offer education to men more especially in the construction sector to treat women construction workers well in Africa, including provision of good security and facilities to women. This recommendation will also support the construction industry to retain women as workers in the sector.

This research study also recommends continued and further research in this important area of women's construction health and safety in Africa. Through this study it was noted that there are many evidence-based research topics and recommendations that can be generated to address needs of women in construction for the specific different countries in Africa, which can be championed by Masters and Doctorate students in the DUT-MAK research collaboration project for construction careers like construction management, quantity surveying, real estate development, land surveying, architecture and engineering in the future. This is essential as Africa has 55 countries that are diverse and unique in their own contexts (Chikafalimani, Kibwami \& Moyo 2021).

\section{Acknowledgements Competing interests}

The authors declare that they have no financial or personal relationships that may have inappropriately influenced them in writing this article.

\section{Authors' contributions}

All authors contributed equally to this work.

\section{Ethical considerations}

This article followed all ethical standards for research study without any direct contact with human or animal subjects.

\section{Funding information}

This research work received no specific grant from any funding agency in the public, commercial or not-for-profit sectors.

\section{Data availability}

Data sharing is not applicable to this article as no new data were created or analysed in this study.

\section{Disclaimer}

The views and opinions expressed in this article are those of the authors and do not necessarily reflect the official policy or position of any affiliated agency of the authors.

\section{References}

Alewi, M., Talukhaba, A. \& Opaleye, O., 2016, 'Women's health and safety in the construction industry in South Africa', 9th CIDB Postgraduate Conference, February 2-4, Cape Town, South Africa, pp. 386-398.

American Society of Safety Professionals Report, 2021, Women and safety in the modern workplace, viewed 18 August 2021, from www.au.int.en.

Chikafalimani, S.H.P., Kibwami, N., \& Moyo, S., 2021, 'Perceptions of academics on real estate topics in Africa', Real Estate Management and Valuation 29(1), 30-40.

Chiocha, C., Smallwood, J. \& Emuze, F., 2011, 'Health and safety in the Malawian construction industry', Acta Structilia 18(1), 18-28.

Construction Industry Development Board (CIDB) Quarterly Monitor, 2020, Construction employment in South Africa, CIDB, Johannesburg.

Creswell, J., 2014, A concise introduction to mixed research methods, Sage, Los Angeles, CA.

English, J., Haupt, T. \& Smallwood, J., 2006, 'Women, construction and health and safety (H\&S): South African and Tanzanian perspectives', Journal of Engineering, Design and Technology 4(1), 18-28.

Ghani, R., 2017, 'Is PPE working for women?', Occupational Health at Work 13, 32-35. Institution of Surveyors of Uganda (ISU) Report, 2021, Gender statistics, ISU, Kampala. International Labour Organization Report, 2010, Providing safe and healthy workplaces for both women and men, ILO, Geneva.

Nordberg, C. \& Johansson, M., 2021, 'Women and ideal women: The representation of women in the construction industry', Gender Issues 38, 1-24.

Okonkwo, P., 2019, 'Health and safety management and performance among construction contractors in South Africa', PhD dissertation unpublished, University of Stellenbosch, Stellenbosch.

Okwel, M., Alinaitwe, H. \& Kalumba, D., 2019, 'Health and safety performance in the Ugandan construction industry', in P. Manu, F. Emuze, T.A. Saurin \& B.H.W. Hadikusumo (eds.), Construction health and safety in developing countries, 1 st edn., pp. 103-115, Routledge, New York, NY.

Oyewobi, L., Oke, A., Adeneye, T. \& Jimoh, R., 2019, 'Influence of organizational commitment on work-life balance and organizational performance of female
construction professionals in Nigeria', Engineering, Construction and Architectural construction professionals in Nigeria', Enginee
Management Journal 26(10), 2243-2263.

Strachan, R., Peixoto, A., Emembolu, I., \& Restivo, M.T., 2018, 'Women in engineering: Addressing the gender gap, exploring trust and our unconscious bias', in 2018 IEEE Global Engineering Education Conference (EDUCON) proceedings, Santa Cruz de Tenerife, Canary Islands, Spain, April 17-20, pp. 2088-2093.

World Bank Report, 2019, Gender assessment, recommendations and action plan, WB, Washington, DC

World Health Organization Report, 2011, Building healthy and equitable workplaces for women and men, WHO, Geneva.

Zengin-Arslan, B., 2002, 'Women in engineering education in Turkey: Understanding the gendered distribution', International Journal of Engineering Education 18(4), 400-408. 